\title{
Bacterial nanocellulose and titania hybrids: cytocompatible and cryopreservable cell carriers
}

Irene Anton-Sales, Soledad Roig-Sanchez, María Jesús Sánchez-Guisado, Anna Laromaine* and Anna Roig*

Institute of Materials Science of Barcelona (ICMAB-CSIC), Campus UAB, 08193 Bellaterra, Catalonia, Spain.

* alaromaine@icmab.es*

\begin{abstract}
Carrier-assisted cell transplantation offers new strategies to improve the clinical outcomes of cellular therapies. Bacterial nanocellulose (BC) is an emerging biopolymer that might be of great value in the development of animal-free, customizable and temperature-stable novel cell carriers. Moreover, BC exhibits a myriad of modification possibilities to incorporate additional functionalities. Here, we have synthesized $\mathrm{BC}$-titanium dioxide $\left(\mathrm{TiO}_{2}\right)$ nanocomposites $\left(\mathrm{BC} / \mathrm{TiO}_{2}\right)$ to evaluate and compare the suitability of not only $\mathrm{BC}$ but also a model hybrid nanobiomaterial as cell transplantation supports. This work provides thorough information on the interactions between BC-based substrates and model human cells in terms of cell attachment, morphology, proliferation rate and metabolic activity. Two methods to partially retrieve the adhered cells are also reported. Both $\mathrm{BC}$ and $\mathrm{BC} / \mathrm{TiO}_{2}$ substrates are positively evaluated in terms of cytocompatibility and endotoxin content without detecting major differences between $\mathrm{BC}$ and $\mathrm{BC}$ nanocomposites. Lastly, the effective cryopreservation of cells- $\mathrm{BC}$ and cells- $\mathrm{BC} / \mathrm{TiO}_{2}$ constructs, yielding high cell viability and intact cell carriers after thawing, is demonstrated. Taken together, our results show that both $\mathrm{BC}$ and $\mathrm{BC} / \mathrm{TiO}_{2}$ enable to integrate the processes of expansion and long-term storage of human cells in transportable, robust and easy to manipulate supports. We expect these findings to encourage further applications of BC-based biomaterials in cellular therapies and to prompt research on BC-nanocomposites exhibiting advanced functionalities.
\end{abstract}

\section{KEYWORDS}

- Microbial cellulose

- Nanocomposites

- Titania

- Cryopreservation

- Fibroblasts

- Cell culture support

\section{INTRODUCTION}

Cell transplantation approaches rely on a dual beneficial effect evoked by the administered cells: i) repopulation of the wound bed and ii) contribution towards a favourable microenvironment for tissue repair (via secretion of cytokines and growth factors). Cellular therapies in the form of autologous ${ }^{1,2}$ or allogenic ${ }^{3}$ cell transplants exhibit a long-proven efficacy to treat complicated skin lesions; while extending these therapies to other organs ${ }^{4}$ and developing innovative cell delivery systems ${ }^{5}$ represents an active focus of research. Despite some satisfactory clinical outcomes have already been obtained ${ }^{6,7}$, the complex administration of therapeutic cells i.e., insufficient survival and integration of cells delivered in suspensions or sprays ${ }^{8-10}$, hinders the widespread implementation of some cell therapies. Moreover, the next generation of cellular products should be provided in a ready-to-use format to decrease waiting times and be used ondemand. To this end, long-term and reliable storage (e.g. cryopreservation) of cellular products 
needs to be further developed and standardized. The use of cell carriers can contribute to overcoming some of these bottlenecks; specifically by enhancing cell survival, controlling differentiation and retaining the transplanted cells at the target site. Last but not least, cell vehicles can also facilitate cryopreservation and the handling of therapeutic cells ${ }^{11}$.

Collagen-based biomaterials represent the current gold standard for cell transplantation supports mainly because of its ability to support cell attachment and proliferation ${ }^{8,12}$. However, collagen presents some disadvantages such as a certain risk of immunogenicity, poor batch-to-batch reproducibility and low availability all due to its animal origin. Nanocellulose synthesized by bacteria (referred here as bacterial nanocellulose, BC) is a biopolymer with potential applicability as an alternative cell carrier. BC inherently presents many of the characteristics sought-after for cell transplantation supports namely; purity, conformability, water holding capacity and porosity ${ }^{13}$. Besides, the high thermal and mechanical stability of BC are favourable features for the clinical translation since they enable heat-sterilization, easy handling and fixation by suturing ${ }^{14}$. The interwoven nanofibrillar structure of $\mathrm{BC}$ is responsible for most of these unique physicochemical properties and the high architectonical similarity to collagenous structures. BC was first proposed as a substrate for mammalian cell culture in the 1990s by Watanabe et al ${ }^{15}$. Later studies have reported on $\mathrm{BC}$ functionalized with the tripeptide motif RGD for the culture of fibroblasts ${ }^{16}$ or surface-modified BC as support for retinal pigment epithelial cells ${ }^{17,18}$. However, uncoated BC substrates have also been successfully loaded with several cells types ${ }^{19-21}$ and proved to prolong stemness of mouse embryonic stem cells ${ }^{22}$. These findings imply that BC could be deemed as an alternative to collagen in the design of novel carriers for cell transplantation therapies ${ }^{23}$ and in vitro studies ${ }^{24}$. On the other hand, BC has been suggested as a cryoprotectant agent ${ }^{25}$ and other cellulosic materials have been employed as substrates to cryopreserve embryos ${ }^{26}$ and fungi ${ }^{27}$. However, the possibility to cryopreserve BC-cell constructs has not been addressed so far.

Considering the remarkable functional properties that inorganic nanoparticles (NPs) can endow to $\mathrm{BC}$ and the rising research attention on hybrid biomaterials ${ }^{28}$, it is of great interest to investigate the impact of these NPs on cells cultured on such BC nanocomposites. Because of its widespread use in skin-related applications, titanium dioxide $\left(\mathrm{TiO}_{2}\right) \mathrm{NPs}$ were selected here as a model NP among the plethora of biocompatible NPs to be combined with BC. Importantly, colloidal $\mathrm{TiO}_{2}$ NPs have recently been suggested for dermal treatments as antimicrobial and scar-reducing agents ${ }^{29,30}$. $\mathrm{TiO}_{2} \mathrm{NPs}$ have also been incorporated to plant-derived nanocellulose patches as a linker for drug molecules to modulate release kinetics ${ }^{31,32}$. In another study, $\mathrm{TiO}_{2} \mathrm{NPs}$ combined with $\mathrm{BC}$ films created an efficient wound dressing in a burn mice model ${ }^{33}$. Nevertheless, the role of $\mathrm{TiO}_{2}$ on the performance of $\mathrm{BC}$ as a cell carrier has never been systematically studied.

Here, we present a thorough study of $\mathrm{BC}$ and $\mathrm{BC} / \mathrm{TiO}_{2}$ nanocomposites as versatile and portable cell culture supports. The two substrates are structurally characterized and proven endotoxin-free and then in vitro studies on cell attachment, proliferation, viability and morphology are described. Next, three methods to retrieve the cells adhered to $\mathrm{BC}$ and $\mathrm{BC} / \mathrm{TiO}_{2}$ supports are tested. Finally, we show that cell-BC and cell- $\mathrm{BC} / \mathrm{TiO}_{2}$ constructs can be effectively cryopreserved yielding highly viable cell populations and intact carriers after thawing.

\section{EXPERIMENTAL}

\section{$\mathrm{BC}$ and $\mathrm{BC} / \mathrm{TiO}_{2}$ substrates: synthesis and characterization}

\section{Bacterial nanocellulose production}

A commercial Komagataeibacter xylinus (K. xylinus) strain (NCIMB 5346 from CECT, Valencia, Spain) was initially cultured in Hestrin-Schramm (HS) solid medium consisting of $1.15 \mathrm{~g}$ citric acid, $6.8 \mathrm{~g} \mathrm{Na}_{2} \mathrm{HPO}_{4} \cdot 12 \mathrm{H}_{2} \mathrm{O}, 5 \mathrm{~g}$ peptone, $5 \mathrm{~g}$ yeast extract, $15 \mathrm{~g}$ agar and $20 \mathrm{~g}$ dextrose all from Condalab for $1 \mathrm{~L}$ of Milli-Q water. Next, a bacterial inoculum was picked with a loop and used 
to inoculate $6 \mathrm{~mL}$ of $\mathrm{HS}$ liquid medium (same composition as the solid medium but without agar) and this culture was expanded during 7 days at $30^{\circ} \mathrm{C}$. Then, $0.5 \mathrm{~mL}$ of the previous broth was mixed with $4.5 \mathrm{~mL}$ of fresh HS liquid medium and further incubated for 7 days. Finally, a 1:14 dilution of the former bacterial solution was performed with fresh medium and transferred to 24 well-plates ( $2 \mathrm{~mL} /$ well). The culture remained 3 days at $30^{\circ} \mathrm{C}$ under static conditions and circular $\mathrm{BC}$ hydrogels formed at the air-liquid interface of every well with the same diameter as the container $\left(\approx 2 \mathrm{~cm}^{2}\right)$. BC pellicles were picked with plastic tweezers and soaked in a solution of 1:1 Ethanol: deionized water (DI) for 10 min to kill the bacteria.

The exhaustive cleaning process of the $\mathrm{BC}$ involved different boiling steps; i) 40 minutes in DI water and ii) two periods of 20 minutes in $0.1 \mathrm{M} \mathrm{NaOH}$ (Sigma-Aldrich) aqueous solution to remove all organic residues. Lastly, $\mathrm{BC}$ films were rinsed with $\mathrm{DI}$ water until neutral $\mathrm{pH}$ was reached. Then, the films were autoclaved $\left(121^{\circ} \mathrm{C}, 20 \mathrm{~min}\right)$ and stored in DI water at room temperature until further use. If needed, $\mathrm{BC}$ samples were dried at $60{ }^{\circ} \mathrm{C}$ between two Teflon plates under a $1 \mathrm{~kg}$ weight.

\section{Bacterial nanocellulose functionalization with $\mathrm{TiO}_{2}$ nanoparticles}

For the $\mathrm{BC}$ functionalization with $\mathrm{TiO}_{2} \mathrm{NPs}$, a previously described ${ }^{34,35}$ microwave (CEM Discover Explorer-12 Hybrid reactor operating at a frequency of $2.45 \mathrm{GHz}$ and with a maximum power of $300 \mathrm{~W}$ placed in a clean room) assisted method was employed. Briefly, ever dry BC films were soaked in benzyl alcohol (99\% BA from Scharlau) for approx. 30 minutes to allow solvent exchange and then transferred to a glass tube containing $4 \mathrm{~mL}$ of benzyl alcohol and 140 $\mu \mathrm{L}$ of titanium (IV) butoxide (TBOT, 97\%, Sigma-Aldrich). All the precursors were mixed immediately before starting the microwave reaction to avoid hydrolysis of the titanium precursor. The reaction vessel was heated in two steps: 1) $5 \mathrm{~min}$ at $50^{\circ} \mathrm{C}$ 2) $10 \mathrm{~min}$ at $190{ }^{\circ} \mathrm{C}$. After the reaction, the $\mathrm{BC} / \mathrm{TiO}_{2}$ films were rinsed once with ethanol to remove the excess of NPs and several times with DI water until reaching a neutral $\mathrm{pH}$. After $\mathrm{TiO}_{2}$-functionalization, the never dry $\mathrm{BC}$ films were dried at $60^{\circ} \mathrm{C}$ between two Teflon plates under $1 \mathrm{~kg}$ weight.

\section{Endotoxin contamination study}

According to the FDA recommendations ${ }^{36}$, the endotoxin extraction was carried out by placing autoclaved $\mathrm{BC}$ and $\mathrm{BC} / \mathrm{TiO}_{2}$ never dry samples in depyrogenated falcon tubes with $40 \mathrm{~mL}$ of endotoxin-free water during $72 \mathrm{~h}$ at $30^{\circ} \mathrm{C}$ and under orbital agitation (100 rpm). To evaluate the endotoxin content in the eluates from $\mathrm{BC}$ and $\mathrm{BC} / \mathrm{TiO}_{2}$ films, a Pierce ${ }^{\mathrm{TM}} \mathrm{LAL}$ Chromogenic Endotoxin Quantification Kit was purchased from Thermo Fisher and the assay was performed following the kit's instructions. The products of the reaction were measured for absorbance at 405 $\mathrm{nm}$ in a microplate reader (Infinite 200 PRO, TECAN ${ }^{\circledR}$ ) at $37{ }^{\circ} \mathrm{C}$. The indicated values correspond to the mean \pm standard deviation of two independent experiments obtained from two different endotoxin quantification kits and evaluating each time two samples from two different batches of BC.

\section{Scanning electron microscopy (SEM)}

Dry $\mathrm{BC}$ and $\mathrm{BC} / \mathrm{TiO}_{2}$ films were fixed flat on top of aluminium SEM sample holders with adhesive carbon tape. The samples were coated with $5 \mathrm{~nm}$ of platinum before imaging. A highresolution scanning electron microscope (FEI Magellan 400L XHR SEM) was used under high vacuum with an acceleration voltage of $2 \mathrm{kV}$. To image the $\mathrm{BC} / \mathrm{TiO}_{2}$ samples without Pt coating, the same sample preparation without the sputtering step was performed. Energy-dispersive X-ray (EDX) spectroscopy was performed with the same equipment on two $\mathrm{BC} / \mathrm{TiO}_{2}$ samples.

Atomic force microscope (AFM) 
To obtain topographical images and roughness measurements of $\mathrm{BC}$ and $\mathrm{BC} / \mathrm{TiO}_{2}$ pellicles, a 5100 Agilent Technologies atomic force microscopy was employed on tapping mode and equipped with a FORT tip form AppNano. At least three $30 \times 30 \mu \mathrm{m}$ or $50 \times 50 \mu \mathrm{m}$ images were obtained for four different dry $\mathrm{BC}$ and $\mathrm{BC} / \mathrm{TiO}_{2}$ films. The images were processed with Surface analysis software V7.4 (64-bit) - Mountains technology. The indicated roughness values correspond to mean \pm standard deviations.

Thermo-gravimetric analysis (TGA)

Thermal decomposition studies were performed with a NETZSCH -STA 449 F1 Jupiter analyser employing a heating rate of $10^{\circ} \mathrm{C}$ per minute from 25 to $600{ }^{\circ} \mathrm{C}$ at an air atmosphere. Three dry $\mathrm{BC}$ and three dry $\mathrm{BC} / \mathrm{TiO}_{2}$ samples were analysed.

Inductively coupled plasma - optical emission spectroscopy (ICP-OES)

Dry $\mathrm{BC} / \mathrm{TiO}_{2}$ samples were immersed in $8 \mathrm{~mL}$ of water during one month under mild agitation and then the eluates were collected for analysis with an ICP-OES Optima 4300DV Perkin-Elmer.

\section{Transmission electron microscopy (TEM)}

The nanoparticles characterization was performed through JEOL JEM-1210 electron microscope operating at $120 \mathrm{kv}$ with an ORIUS 831 SC 600 Gatan camera. TEM images were analysed with Image $\mathbf{J}$ software and a histogram of 360 nanoparticles was fitted to a Gaussian function. The percentage of standard deviation divided mean value was obtained as the polydispersity value. Selected area electron diffraction (SAED) was used to obtain diffraction patterns from the $\mathrm{TiO}_{2}$ nanoparticles.

\section{$\mathrm{BC}$ and $\mathrm{BC} / \mathrm{TiO}_{2}$ substrates: evaluation as cell carriers}

\section{In vitro studies}

For the in vitro experiments, a human dermal fibroblast cell line was used (1BR3.G cells, ECACC 90020507) as a model. The cultures were maintained in Dulbecco's Modified Eagle Medium (DMEM) supplemented with $2 \mathrm{mM}$ GlutaMax and $10 \%$ foetal bovine serum (South American FBS) both from Gibco and monitored with an inverted optical microscope (Nikon Eclipse TS100). 1BR3.G cells were kept in a T75 flask (Sarstedt) at $37^{\circ} \mathrm{C}$ in $10 \% \mathrm{CO}_{2}$ and split three times per week.

For all the experiments detailed in this section, dry $\mathrm{BC}$ and $\mathrm{BC} / \mathrm{TiO}_{2}$ samples were rehydrated in DI water and autoclaved $\left(121{ }^{\circ} \mathrm{C}, 20 \mathrm{~min}\right)$ before being used as cell supports. To plate the cells, $\mathrm{BC}$ and $\mathrm{BC} / \mathrm{TiO}_{2}$ films were preconditioned with warm DMEM and then transferred to 24-well plates using forceps and irradiated with UV light for 30 minutes to ensure sterility. A concentrated cell suspension $(50.000$ cells/well for the proliferation study and 100.000 cells/well for the rest of the experiments) was carefully pipetted on the middle of the pellicles. When the cell suspension was absorbed by the BC films, $500 \mu \mathrm{L}$ of fresh culture medium were added to each well. See Figure S2 for an illustration of this process. Controls (uncoated commercial cell culture plates) were seeded with the same procedure and number of cells than the substrates.

Cell proliferation was assessed qualitative by optical microscope and quantitatively with the CellTiter-Glo ${ }^{\circledR}$ Luminescent Cell Viability Assay (Promega) by measuring ATP levels on the cultures at Day 1, Day 3 and Day 8 after cell seeding. For this assay, all the elements were accommodated at RT and then the cell-loaded films were transferred to unused culture wells and washed with PBS before adding $100 \mu \mathrm{L}$ of the CellTiter-Glo® reagent to each well together with $100 \mu \mathrm{L}$ of DMEM. The 24 multiwell plates were agitated for 2 minutes to lysate the cells and then incubated during 10 minutes at RT to stabilize the luminescence. After careful mixing, $150 \mu \mathrm{L}$ of 
the supernatant of each well were transferred to a 96 well plate with an opaque bottom for the luminescent read. Blanks were performed with plain BC films and culture medium without cells. Luminescence was read with a Tecan Spark ${ }^{\circledR}$ multimode microplate reader (LifeSciences) with an integration time of $1000 \mathrm{~ms}$. The experiment was performed three times with three technical replicates at each time point.

Cell viability, distribution and morphology were studied with a confocal laser scanning microscope (Leica SP5) 48 hours after plating the cells. Calcein-AM (BD Pharmingen ${ }^{\mathrm{TM}}$ ) staining was used to monitor the viability of the cells growing on $\mathrm{BC}$ and $\mathrm{BC} / \mathrm{TiO}_{2}$ supports since this reagent becomes fluorescent after being cleaved by intracellular esterases that are only present on alive cells. Cell-loaded $\mathrm{BC}$ and $\mathrm{BC} / \mathrm{TiO}_{2}$ films were washed with Hank's Balanced Salt Solution (HBSS, Gibco) and then incubated during 15 minutes in the dark with $1 \mathrm{~mL} /$ sample of $4 \mu \mathrm{g} / \mathrm{mL}$ Calcein-AM in HBSS and washed twice with HBSS. Then the cells were fixed with $4 \%$ cold paraformaldehyde (Panreac) during 5 minutes. Fixed cells were further stained during 5 minutes with $1 \mu \mathrm{g} / \mathrm{mL}$ of Hoechst 33342 (Invitrogen, cell nuclei, blue) and $5 \mu \mathrm{g} / \mathrm{mL}$ CellMask ${ }^{\mathrm{TM}}$ Deep Red Plasma Membrane Stain (Invitrogen, cell membranes, red) diluted in PBS and rinsed again. Calcein was excited at a wavelength of $495 \mathrm{~nm}$, Hoesch at $350 \mathrm{~nm}$ and Cell Mask at $588 \mathrm{~nm}$. The $\mathrm{BC}$ and $\mathrm{BC} / \mathrm{TiO}_{2}$ films were flipped so that the cells faced the surface of Ibidi Glass Bottom dishes to be imaged with 10X (dry), 20X (dry) or 40X (oil) objectives. Several images of different $\mathrm{z}$ planes were obtained for each sample so that all the cross-section off the sample was covered. These stacks of images were then used to generate 3D reconstructions with the Fiji package of ImageJ (64-bit version). Cell shape descriptors were analysed with the same software by measuring $>60$ cells for each condition from images taken from three independent experiments. For the axial ratio, the length of the longer axis of each cell was divided by the length of the shortest axis. Circularity was calculated as $4 \pi^{*}\left(\right.$ cell area/cell perimeter $\left.{ }^{2}\right)$. The nuclearcytoplasmic ratio ( $\mathrm{N}: \mathrm{C}$ ratio) was obtained by diving the nuclear area between the total area of the cell. To fluorescently stain the substrates (Images in Figure 1 and 2), rewet $\mathrm{BC}$ and $\mathrm{BC} / \mathrm{TiO}_{2}$ films were stained with Safranin-O (Alfa Aesar, 0.01\% weight/volume dilution in DI water) overnight and rinsed several times before plating the cells. The Safranin-O dye was excited with a $495 \mathrm{~nm}$ laser.

\section{Cryopreservation of cell-biomaterial constructs}

For the cryopreservation experiment, 100.000 1BR3.G cells were seeded on triplicates on BC and $\mathrm{BC} / \mathrm{TiO}_{2}$ rewet films and conventional cell culture surfaces (controls) and expanded until highly confluent cultures were achieved; 1 week for $\mathrm{BC}$ and $\mathrm{BC} / \mathrm{TiO}_{2}$ substrates and 5 days for controls. Cell-loaded $\mathrm{BC}$ and $\mathrm{BC} / \mathrm{TiO}_{2}$ films were transferred to $1.8 \mathrm{~mL}$ cryovials (Nunc) containing $1 \mathrm{~mL}$ cryopreservation medium consisting of $90 \%$ FBS and $10 \%$ cell culture grade DMSO. Controls cells were detached from the culture wells using Trypsin-EDTA, centrifuged for 5' at $1400 \mathrm{rpm}$ and then re-suspended in $1 \mathrm{~mL}$ of the same cryopreservation medium and transferred to cryovials. The cryovials were kept overnight inside a CoolCell® container at $-80{ }^{\circ} \mathrm{C}$ to allow a controlled freezing rate of $-1{ }^{\circ} \mathrm{C} /$ minute. Then, the vials were stored for at least one week at $-196{ }^{\circ} \mathrm{C}$ on a liquid nitrogen tank. $\mathrm{BC}$ and $\mathrm{BC} / \mathrm{TiO}_{2}$ films without cells were included to monitor the material stability upon cryostorage.

All the vials were thawed directly by immersion on a $37{ }^{\circ} \mathrm{C}$ water bath. The $\mathrm{BC}$ and $\mathrm{BC} / \mathrm{TiO}_{2}$ films were carefully transferred to 24 well plates containing fresh culture medium using tweezers. Control cells were precipitated upon centrifugation and re-suspended in warm DMEM before being transferred to culture well plates. 24 hours later, the medium was changed to remove DMSO remains. Cell recovery was assessed at three time-points: before cryopreservation, 4 and 48 hours after thawing. Cell morphology was monitored with a contrast phase microscope and cell viability was qualitatively evaluated with Calcein-AM staining (described in the previous section) and quantitatively with the CellTiter-Glo® Luminescent Cell Viability Assay also detailed before 
performing the luminescence reads with a VICTOR 3 plate reader (PerkinElmer). Cell viability after thawing was calculated for each condition relative to the luminescent signal obtained for the not cryopreserved samples.

\section{Cell retrieve}

For the trypsin-based cell retrieve experiment, $\mathrm{BC}, \mathrm{BC} / \mathrm{TiO}_{2}$ films and controls (cell culture plates) were used as supports to plate 100.000 1BR3.G cells as previously described (triplicates). To estimate the number of cells that attached to the supports, the number of unattached cells, floating on the culture medium, was counted 4 hours after platting as follows: Subsequently to exhaustive homogenization, a sample of $10 \mu \mathrm{L}$ of the cell suspension was mixed with $10 \mu \mathrm{L}$ of Trypan Blue Stain $(0.4 \%$, Gibco) to count the number of cells that were not attached to the BC and $\mathrm{BC} / \mathrm{TiO}_{2}$ substrates using a Neubauer chamber. 48 hours later, the same cell cultures were washed thoroughly with PBS (Gibco) and trypsinized using $250 \mu \mathrm{L}$ trypsin-EDTA $(0.05 \%$, Gibco)/well during 5 minutes. The enzyme was neutralized with $500 \mu \mathrm{L}$ of DMEM and the cells that were floating on the medium were counted in the same manner. To estimate the percentage of recovered cells, the initial number of attached cells (100.000 minus the number of not attached cells) was multiplied by the cell proliferation rate calculated for $\mathrm{BC}$ and $\mathrm{BC} / \mathrm{TiO}_{2}$ after 48 hours of culture to obtain the theoretical number of cells present on each film. Then the percentage of recovered cells was estimated by diving the number of detached cells upon trypsinization between the expected numbers of cells for each film. Optical microscopy observations were also conducted to match these calculations. The cell recovery was considered to be $100 \%$ for the controls and the experiment was repeated three times.

To study cell retrieve via migration of cells from $\mathrm{BC}$ films to other substrates, 100.000 1BR3.G cells were seeded by triplicate on rewet $\mathrm{BC}$ and $\mathrm{BC} / \mathrm{TiO}_{2}$ films and cultured for 48 hours. Then, the films were placed upside-down with the cells contacting the new substrates (cell culture plate and never dry BC hydrogels) using tweezers and further incubated for 72 hours. After that, the original films were removed and the migration/transference of cells was qualitatively evaluated with an optical microscope. Migrated-cell's viability was confirmed upon Calcein-AM staining. The experiment was repeated three times.

The third method tested to recover cells from $\mathrm{BC}$ and $\mathrm{BC} / \mathrm{TiO}_{2}$ substrates consisted of the enzymatic dissolution of the substrates using cellulase. Three samples of $\mathrm{BC}$ and $\mathrm{BC} / \mathrm{TiO}_{2}$ were seeded with 100.000 1BR3.G cells and incubated until reaching high confluence. Then, the samples were rinsed with PBS incubated with a commercial mix of cellulases (GrowDase ${ }^{\mathrm{TM}}$, UPM Biomedicals) at $37^{\circ} \mathrm{C}$ until cellulose degradation as observed. Two different concentrations of cellulase were tested: i) $0.45 \mathrm{mg} / \mathrm{sample}$ and $0.675 \mathrm{mg} /$ sample diluted in culture medium in a total volume of $300 \mu \mathrm{L}$. BC degradation was monitored and photographed with an inverted optical microscope (Nikon Eclipse TS100).

\section{Statistical analysis}

Quantitative data are expressed as means \pm standard deviation. Statistical analyses were performed with Graph Pad Prism 5 software using one-way ANOVA followed by Tukey's multiple comparison test. To compare two different experimental conditions Student's T-tests were conducted. Statistical significance was accepted when obtained P-values were $\leq 0.05$ and summarized as $*=<0.05, * *=<0.01, * * *=<0.001$ for the calculated $\mathrm{P}$-values.

\section{RESULTS AND DISCUSSION}

\section{Substrate characterization}

BC directly obtained from the K.xylinus cultures are hydrogels with a water content of $>100$ times its own dry weight and a typical thickness of $\sim 800 \mu \mathrm{m}$. These samples are semi-transparent after 
cleaning, sturdy and easy to manipulate and here are referred to as 'never dry BC'. When never dry $\mathrm{BC}$ is dried at $60^{\circ} \mathrm{C}$ under $1 \mathrm{~kg}$ weight, its thickness reduces to $\sim 20$ micron and samples acquire a paper-like appearance. Upon rehydration, the dry films do not absorb as much water as the never dry BC and exhibited a thickness of $\sim 23 \mu \mathrm{m}^{37}$. The rehydrated BC samples are referred to as 'rewet BC'. Figure $\mathrm{S} 1$ includes digital images of each type of $\mathrm{BC}$ and other characteristics of the substrates. To create the $\mathrm{BC} / \mathrm{TiO}_{2}$ nanocomposites, never dry $\mathrm{BC}$ films were functionalized with nanotitania via a microwave-assisted thermal decomposition method previously reported ${ }^{34}$ and summarized in Figure 1A. This one-step (15 min reaction time) hydrothermal reaction allowed uniform nucleation of $\mathrm{TiO}_{2} \mathrm{NPs}$ directly on the $\mathrm{BC}$ fibres as evidenced by the whitish colour acquired by the $\mathrm{BC}$ samples (See Figure $\mathrm{S} 1$ ). Never dry $\mathrm{BC} / \mathrm{TiO}_{2}$ was dried with the same procedure and its thickness reduced to $\sim 30$ microns. Rewet $\mathrm{BC} / \mathrm{TiO}_{2}$ films were slightly thicker ( 35 microns) than rewet $\mathrm{BC}$. The handling of the $\mathrm{BC} / \mathrm{TiO}_{2}$ was comparable to that of plain $\mathrm{BC}$; the samples kept its shape, size and flexibility and we did not observe any sign of deterioration after the microwave reaction.

Before its use as a substrate for cell culture, $\mathrm{BC}$ and $\mathrm{BC} / \mathrm{TiO}_{2}$ films were structurally characterized. To get a macroscopic view of the substrates, confocal microscope imaging of fluorescently stained rewet $\mathrm{BC}$ and $\mathrm{BC} / \mathrm{TiO}_{2}$ substrates was conducted (Figure 1, B and E). Both samples show continuous, flat and rather smooth surfaces only presenting few wrinkles formed during the drying process. Since surface roughness is reported to impact on cell attachment and growth ${ }^{38,39}$, Atomic Force Microscopy (AFM) was used to compare the roughness of the substrates in the dry state. $\mathrm{BC}$ films showed an average roughness of $0.14 \pm 0.03 \mu \mathrm{m}$ whereas $\mathrm{BC} / \mathrm{TiO}_{2}$ were rougher $(0.33 \pm 0.07 \mu \mathrm{m})$ due to the nanoparticle coating (See Figure $1 \mathrm{C}$ and $1 \mathrm{~F}$ ).

Following, scanning electron microscopy (SEM) was used to elucidate fibre organization and nanoparticle distribution on the $\mathrm{BC} / \mathrm{TiO}_{2}$ supports. $\mathrm{BC}$ films showed an unorganized interlaced 3D nanofiber distribution (Figure 1D). Interestingly, this 3D network presents a strong architectonical similarity to collagen, the current gold standard to devise cell transplantation supports. Insert on Figure 1D shows an SEM image of collagen fibres from the amniotic membrane to exemplify this resemblance. $\mathrm{BC} / \mathrm{TiO}_{2}$ exhibits the same nanofibrillar structure than plain $\mathrm{BC}$ with a homogenous and dense coating by the $\mathrm{TiO}_{2} \mathrm{NPs}$ (Figure 1G). The insert of Figure $1 \mathrm{G}$ shows an SEM image $\mathrm{BC} / \mathrm{TiO}_{2}$ without metal sputtering were the $\mathrm{TiO}_{2}$ coating is also visible. Energy-dispersive X-ray Spectroscopy revealed that the atomic contribution of titanium on the surface of $\mathrm{BC} / \mathrm{TiO}_{2}$ substrates accounts for $25 \pm 8 \%$. Both the atomic percentage of titanium and the density and distribution of the $\mathrm{TiO}_{2} \mathrm{NPs}$ coating was very similar between the two sides of the nanocomposite.

Thermo-gravimetric analysis (TGA) was carried out to determine that nanotitania represents $\sim 6$ $\%$ of the dry weight of the $\mathrm{BC} / \mathrm{TiO}_{2}$ composites. TGA was also used to study the long-term stability of the nanocomposites; $\mathrm{BC} / \mathrm{TiO}_{2}$ films immersed in water for one month under mild stirring showed no leaching of titanium. That is, the same weight percentage of titanium was detected before and after the soaking ${ }^{34}$. Accordingly, inductively coupled plasma-optical emission spectroscopy revealed that the amounts of titanium detected in the eluates $\mathrm{BC} / \mathrm{TiO}_{2}$ samples were $<0.02 \mathrm{mg} / \mathrm{L}$. These two experiments confirm that the nanoparticles are chemically bonded to the nanocellulose fibres. This should prevent $\mathrm{TiO}_{2}$ nanoparticles to be released from the substrates and to be internalized by the cells in the next in vitro experiments.

Transmission electron microscopy (TEM) was employed to estimate the particle size distribution from the colloidal $\mathrm{TiO}_{2}$ NPs present on the supernatant of the microwave reaction, being in average $7.1 \pm 1.6 \mathrm{~nm}$ with a polydispersity of a $23 \%$ (Figure S1-C). Finally, TEM on electron diffraction mode was used to determine that the $\mathrm{TiO}_{2}$ crystallized in the anatase phase, see Figure S1-D. 
Together, these observations confirm that the employed microwave synthesis is an effective tool to prepare stable $\mathrm{BC} / \mathrm{TiO}_{2}$ nanocomposites in a fast and reproducible manner, obtaining a uniform coating of the nanocellulosic fibres without compromising the original structural properties of BC.
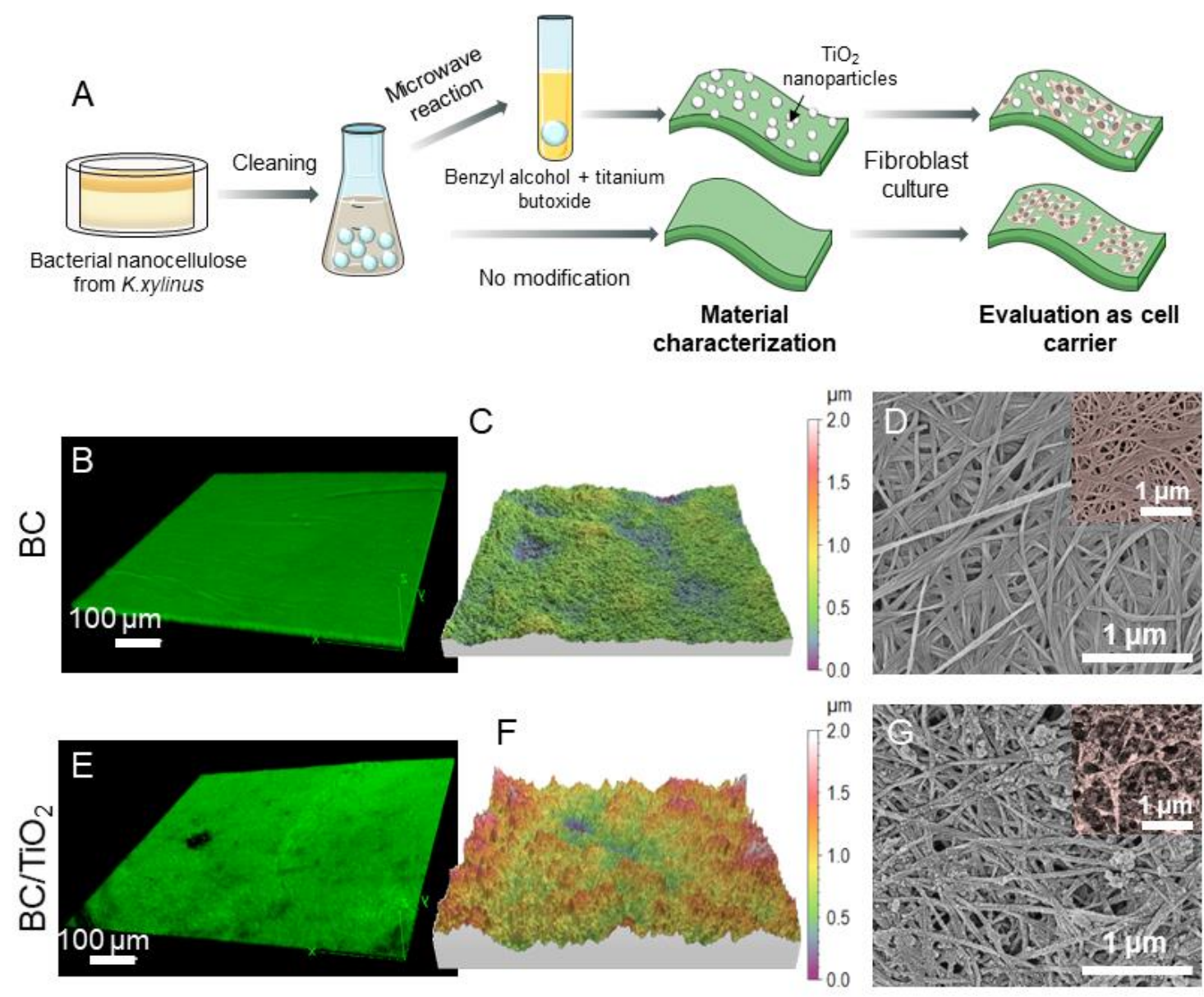

Figure 1: Sample preparation and structural characterization of the $\mathrm{BC}$ and $\mathrm{BC} / \mathrm{TiO}_{2}$ substrates. A) Schematic representation of the processes adopted to prepare $\mathrm{BC}$ and $\mathrm{BC} / \mathrm{TiO}_{2}$ cell carriers. Images $\mathrm{B}$ and E show macroscopic confocal microscope images of rewet $\mathrm{BC}(\mathrm{B})$ and $\mathrm{BC} / \mathrm{TiO}_{2}$ (E) films fluorescently stained with Safranin-O. AFM images $\left(30 \times 30 \mu \mathrm{m}\right.$ areas) are shown on $\mathrm{C}(\mathrm{BC})$ and $\mathrm{F}\left(\mathrm{BC}_{\mathrm{TiO}}\right)$ panels to visualize differences in roughness. Finally, scanning electron microscope (SEM) of $\mathrm{BC}(\mathrm{D})$ and $\mathrm{BC} / \mathrm{TiO}_{2}$ (G) illustrates the nanofibrillar structure of the substrates and the $\mathrm{TiO}_{2}$ coating. Insert on image $\mathrm{D}$ corresponds to a collagen-based biological membrane to visualize the high structural similarities with BC. SEM samples were coated with five $\mathrm{nm}$ of $\mathrm{Pt}$ on images $\mathrm{D}$ and $\mathrm{G}$ and were left uncoated on the insert in image G. Colour was added to facilitate visualization of the inserts.

\section{Endotoxin content}

Endotoxin (also known as lipopolysaccharide) contamination induces a variety of negative biological effects such as airway disease, fever, hypotension, coagulopathies, septic shock and even death, and represents a major problem in biomaterial fabrication. Since BC is synthesized by a gram-negative bacterium, the presence of endotoxins could pose a threat. The amount of endotoxins detected in the eluates of sterile never dry $\mathrm{BC}$ and $\mathrm{BC} / \mathrm{TiO}_{2}$ films were $0.04 \pm 0.01$ and $0.05 \pm 0.01$ Endotoxin Units $(\mathrm{EU}) / \mathrm{mL}$ respectively. Notably, these values are one order of magnitude below the Food and Drug Administration (FDA) obligatory limit of $0.5 \mathrm{EU} / \mathrm{mL}$ applied to medical devices. The low amount of endotoxins detected in the substrates is in accordance with 
the recent literature ${ }^{17,40}$ and indicates that the cleaning protocol of $\mathrm{BC}$ is effective in removing any remains of the $K$. xylinus cell wall.

\section{Cell attachment and morphology}

To investigate the suitability of $\mathrm{BC}$ and $\mathrm{BC} / \mathrm{TiO}_{2}$ as substrates to expand and transplant adherent cells, a model human dermal fibroblast cell line was employed (1BR3.G). Rewet $\mathrm{BC}$ and $\mathrm{BC} / \mathrm{TiO}_{2}$ membranes were selected for the in vitro experiments as the drying-rehydration cycle contributed to reducing the variability between samples and slightly increased the initial cell attachment compared to never dry $\mathrm{BC}$. Accordingly, dry $\mathrm{BC}$ and $\mathrm{BC} / \mathrm{TiO}_{2}$ were rehydrated in $\mathrm{DI}$ water, autoclaved and then seeded with 1BR3.G cells. This tolerance to heat sterilization represents a clear advantage of $\mathrm{BC}$ for future clinical translation. Fibroblasts readily attached to both $\mathrm{BC}$ and $\mathrm{BC} / \mathrm{TiO}_{2}$ substrates without the need of any additional treatment, thus greatly facilitating the seeding protocol. Moreover, the above-mentioned morphological stability of $\mathrm{BC}$ and $\mathrm{BC} / \mathrm{TiO}_{2}$ allowed the easy manipulation and portability of the cell cultures. Figure S2 shows the cell platting protocol, the handling of BC-cells constructs and the monitoring of the cell cultures by phase-contrast microscope. By counting the number of cells that were not attached to the substrates 4 hours after seeding, we could assess that $77 \pm 1 \%$ of the seeded cells adhered to BC and $73 \pm 9 \%$ attached to $\mathrm{BC} / \mathrm{TiO}_{2}$ (not statistically significant differences). Even that the $\mathrm{BC}$ and $\mathrm{BC} / \mathrm{TiO}_{2}$ films have the same size as the culture wells, a small portion of the seeded cells still attached to the underneath tissue culture plate instead of the substrates and therefore these numbers are presented as an approximation. After two days of culture, images from Figure 2A were collected with a confocal microscope where fibroblasts attachment to the $\mathrm{BC}$ and $\mathrm{BC} / \mathrm{TiO}_{2}$ films (stained in green with Safranin-O) is clearly observed. Optical slicing in the z direction revealed that $1 \mathrm{BR} 3 . \mathrm{G}$ cells grew over the entire surface of the $\mathrm{BC}$ and $\mathrm{BC} / \mathrm{TiO}_{2}$ films without penetrating inside the substrates as expected according to the small size of the $\mathrm{BC}$ pores. Figure $\mathrm{S} 3$ shows large area confocal microscope images $\left(\sim 40 \mathrm{~mm}^{2}\right)$ of $\mathrm{BC}$ and $\mathrm{BC} / \mathrm{TiO}_{2}$ substrates 48 hours after seeding to further illustrate fibroblast distribution on the surfaces.

Then, we analysed diverse cell shape descriptors to investigate whether $\mathrm{BC}$ and $\mathrm{BC} / \mathrm{TiO}_{2}$ films were able to facilitate cell spreading recapitulating the characteristic elongated fibroblast phenotype found in vivo. Both supports rendered the expected fibroblast morphology with axial values of $3.9 \pm 1.7$ for $\mathrm{BC} / \mathrm{TiO}_{2}$ and $3.1 \pm 1.3$ for plain $\mathrm{BC}(\mathrm{n}>60$ cells, $\mathrm{P}$-value $<0.005)$. Cell shape descriptors measurements are detailed in Figure S4. Notably, the obtained axial ratios are similar to those reported for fibroblasts seeded on collagen and fibrin coated supports ${ }^{41}$. Cells plated on $\mathrm{BC} / \mathrm{TiO}_{2}$ substrates presented statistically significant higher axial ratio compared to cells cultured on plain $\mathrm{BC}$ as well as larger total cell area. This indicates an enhanced spreading of the fibroblast on the $\mathrm{BC} / \mathrm{TiO}_{2}$ respect to $\mathrm{BC}$ supports (See normalized data on Figure $2 \mathrm{~B}$ ). The nuclearcytoplasmic ratio ( $\mathrm{N}: \mathrm{C}$ ratio), i.e. the relative area of the cytoplasm respect to the nucleus ${ }^{42}$, was significantly smaller for cells seeded on $\mathrm{BC} / \mathrm{TiO}_{2}$ further supporting that cells tend to extend more on the hybrid substrates. We ascribe these effects to the greater roughness of the $\mathrm{BC} / \mathrm{TiO}_{2}$ substrates which might provide more anchoring sites for the fibroblasts $38,39,43$.
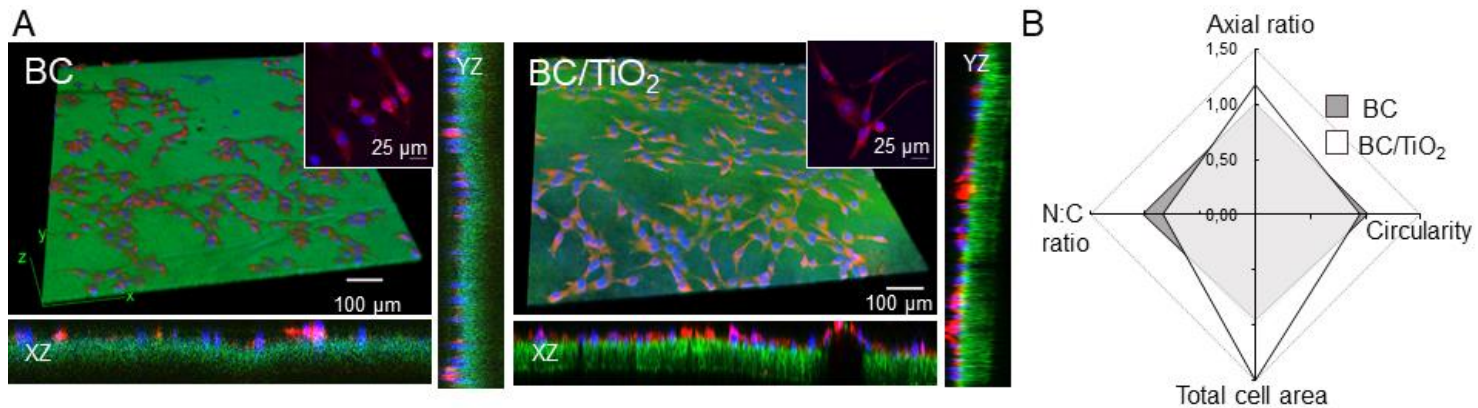
Figure 2: Cell attachment and morphology on $\mathrm{BC}$ and $\mathrm{BC} / \mathrm{TiO}_{2}$ substrates. Panel A shows confocal microscope images of human dermal fibroblasts attached to $\mathrm{BC}$ and $\mathrm{BC} / \mathrm{TiO}_{2}$ supports 48 hours after plating the cells. Insets display zoom in's to better visualize cell morphology and spreading. Cell nuclei (blue) were stained with Hoechst and cell membranes (red) with Cell Mask while $\mathrm{BC}$ and $\mathrm{BC} / \mathrm{TiO}_{2}$ supports were stained with Safranin-O (green). 3D reconstruction of the $\mathrm{z}$ stacks revealed that cells distribute over the BC and $\mathrm{BC} / \mathrm{TiO}_{2}$ films surface without penetrating inside the films (see lateral images for the $\mathrm{xz}$ and yz planes). B) Radar chart comparing the main cell shape descriptors (normalized) measured 48 hours after seeding 1BR3.G cells on $\mathrm{BC}$ and $\mathrm{BC} / \mathrm{TiO}_{2}$ films. $\mathrm{N}: \mathrm{C}$ ratio refers to the nuclear/cytoplasmic ratio. Statistically significant differences were found for the measurements of axial ratio, total cell area and $\mathrm{N}: \mathrm{C}$ ratio suggesting a higher fibroblast spreading on $\mathrm{BC} / \mathrm{TiO}_{2}$ than in plain $\mathrm{BC}$.

\section{Cell viability and proliferation}

To gain insight into the biological activity of the fibroblasts cultivated on top of $\mathrm{BC}$ and $\mathrm{BC} / \mathrm{TiO}_{2}$ substrates, cell viability (Calcein-AM staining) and proliferation kinetics were studied. Figure $3 \mathrm{~A}$ illustrates that cells seeded on both $\mathrm{BC}$ and $\mathrm{BC} / \mathrm{TiO}_{2}$ films exhibit high viability since $98 \%$ and 99\% of the cells were positive for the Calcein-AM staining respectively at day 2 after seeding. Fibroblasts platted on control surfaces exhibited analogous Calcein-AM staining. Then, we monitored cell proliferation over 8 days of culture on $\mathrm{BC}, \mathrm{BC} / \mathrm{TiO}_{2}$ and cell culture plates as positive controls (Figure 3B). A progressive intensification of the signal was observed for the three conditions finding statistically significant differences at Day 8 respect to Day 1 for the $\mathrm{BC}$ and $\mathrm{BC} / \mathrm{TiO}_{2}$ substrates, which correlates with an increasing number of metabolically active cells. Not surprisingly, fibroblasts on the control surfaces exhibit higher absolute values (statistically significant respect to both $\mathrm{BC}$ and $\mathrm{BC} / \mathrm{TiO}_{2}$ ) which we attribute mainly to the higher initial cell attachment to these surfaces compared to the $\mathrm{BC}$ and $\mathrm{BC} / \mathrm{TiO}_{2}$ carriers. No statistically significant differences were found when comparing proliferation between plain $\mathrm{BC}$ and titania hybrids implying that the $\mathrm{TiO}_{2} \mathrm{NPs}$ coating has a neutral effect over fibroblasts proliferation. After one week, the cultures reached $100 \%$ confluence on the three substrates (Figure S2-B) leading to the formation of a continuous cell monolayer. These observations point out that $\mathrm{BC}$ and $\mathrm{BC} / \mathrm{TiO}_{2}$ allow not only the adhesion and spreading of fibroblasts but also its metabolic activity and in vitro expansion. These findings are relevant for future exploitation of $\mathrm{BC}$ and $\mathrm{BC} / \mathrm{TiO}_{2}$ as cells carriers since elevated cell densities are generally required for transplantation.

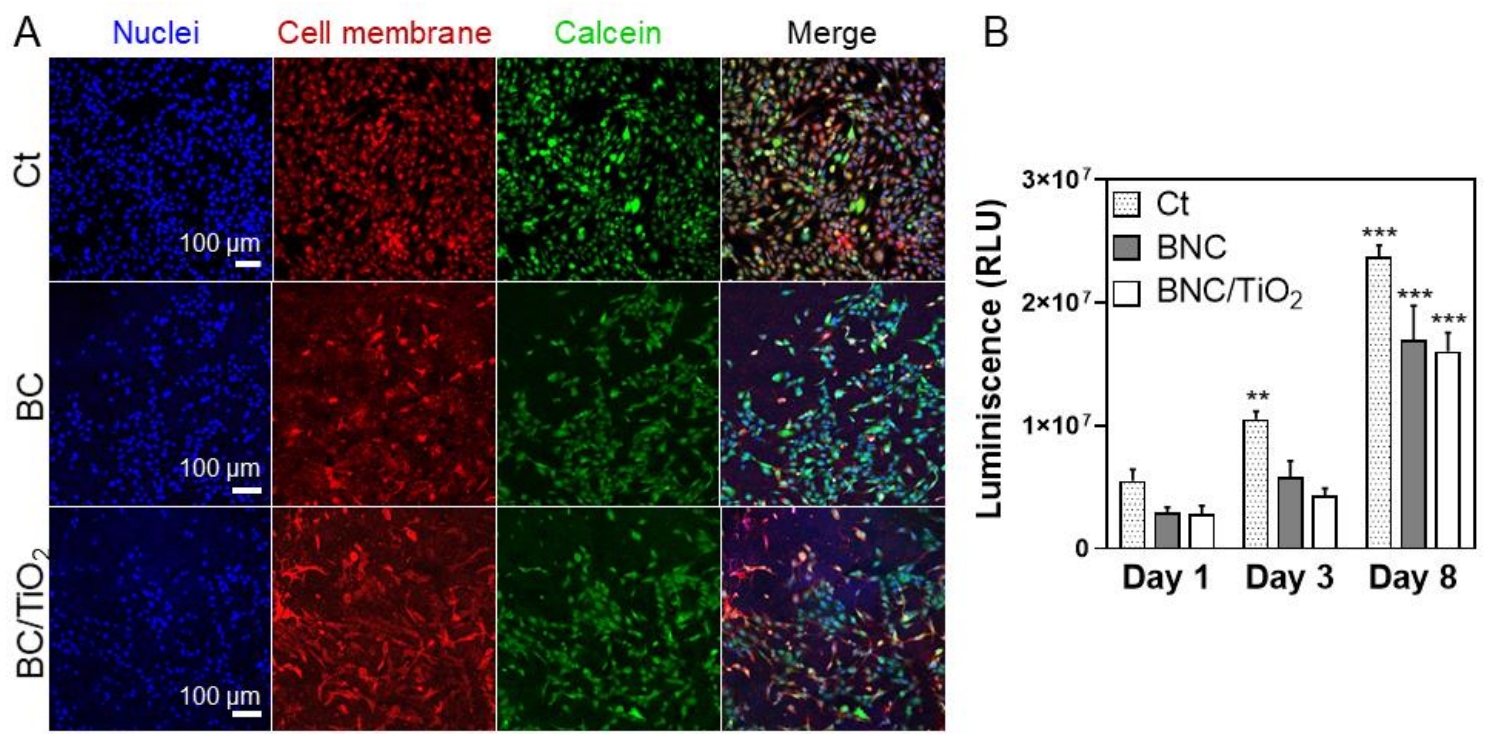

Figure 3: Cell viability and proliferation on $\mathrm{BC}$ and $\mathrm{BC}^{\mathrm{TiO}} \mathrm{O}_{2}$ supports. A) The study of cell viability was carried out with Calcein-AM staining 48 hours after cell seeding. $\mathrm{BC}$ and $\mathrm{BC} / \mathrm{TiO}_{2}$ substrates yielded highly viable cell populations. Confocal microscope images depict cell nuclei (blue) stained with Hoechst and cell membranes (red) with Cell Mask. Viable cells were stained with Calcein-AM (green). The fourth 
column shows the composite of all pictures. B) Proliferation kinetics of the fibroblasts seeded on BC (grey bars) and $\mathrm{BC} / \mathrm{TiO}_{2}$ (white bars) and controls (dotted bars) monitored with the CellTiter-Glo® assay measuring ATP levels. For the studied cell carriers, statistically significant differences were found for Day 8 compared to Day 1 demonstrating the ability of $\mathrm{BC}$ and $\mathrm{BC} / \mathrm{TiO}_{2}$ to support fibroblast proliferation $(\mathrm{n}=3)$.

\section{Cell retrieve}

To further investigate the properties of $\mathrm{BC}$ and $\mathrm{BC} / \mathrm{TiO}_{2}$ substrates as cell culture platforms, we evaluated the possibility to retrieve the cells attached to $\mathrm{BC}$ and $\mathrm{BC} / \mathrm{TiO}_{2}$ substrates by three different methods: conventional trypsinization, direct contact with other substrates and degradation of the nanocellulose carriers.

Cells adhered to $\mathrm{BC}$ and $\mathrm{BC} / \mathrm{TiO}_{2}$ substrates could partially be harvested upon a five-minute incubation with trypsin-EDTA. To be precise, $55 \pm 18 \%$ of the cells could be retrieved from $\mathrm{BC} / \mathrm{TiO}_{2}$ substrates while $35 \pm 15 \%$ of the cells were detached from $\mathrm{BC}$ (not statistically significant differences) yielding a suspension of viable cells that could be used for further studies such as flow cytometry (Figure 4A). By an equivalent trypsinization process of fibroblasts growing on polystyrene plates, virtually the totality of the cells (indicated as $100 \%$ in Figure 4A) was recovered. This observation indicates that both $\mathrm{BC}$ and $\mathrm{BC} / \mathrm{TiO}_{2}$ substrates interfere to some extent with the trypsin-EDTA action, making it a partially effective approach to harvest the cells from the investigated substrates. Figure S-5 contains optical microscope images of the fibroblasts cultures before and after the trypsin treatment further confirming these results.

Secondly, we placed $\mathrm{BC}$ and $\mathrm{BC} / \mathrm{TiO}_{2}$ films loaded with 1BR3.G cells in close contact (turned upside down) with two different substrates: a polystyrene culture plate as an example of a stiff substrate and a never dry BC hydrogel representing a softer surface. With this method, the transference of a fraction of the total adherent cell population (from their initial substrates to the unused ones) was observed (Figure 4B). Remarkably, the fibroblasts that migrated from the BC and $\mathrm{BC} / \mathrm{TiO}_{2}$ films were able to attach to the new supports and were metabolically active as indicated by the positive Calcein-AM staining (inserts in Figure 4B). The migrated cells exhibited a different morphology depending on the substrate where they were transferred; being more spread on the polystyrene plate than on the BC hydrogel. Presumably, this is due to the difference in the acceptor substrate stiffness which is known to influence fibroblast morphology rendering more rounded cell shapes in soft than in stiff substrates ${ }^{44}$. Overall, this preliminary experiment suggests that despite being strongly attached to the $\mathrm{BC}$ and $\mathrm{BC} / \mathrm{TiO}{ }_{2}$ supports, the cultured cells keep their migration abilities, which is useful for future cell transplantation therapies.

Finally, we explored the possibility to benefit from cellulase enzymes to dissolve the $\mathrm{BC}$ and $\mathrm{BC} / \mathrm{TiO}_{2}$ carriers living a bare cell layer similar to that obtained from the cell-sheet technology that is begin developed with the use of thermo-responsive polymers ${ }^{45,46}$. However, this option was dismissed because the optimization of the working conditions of the cellulase enzyme was incompatible with the growth of the cells; being the long incubation time required to completely dissolve the nanocellulose carriers the main inconvenience (see Figure S-6). 
A

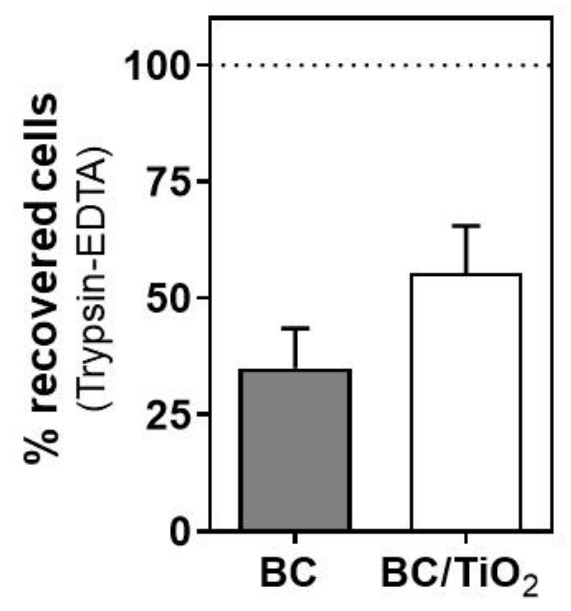

B

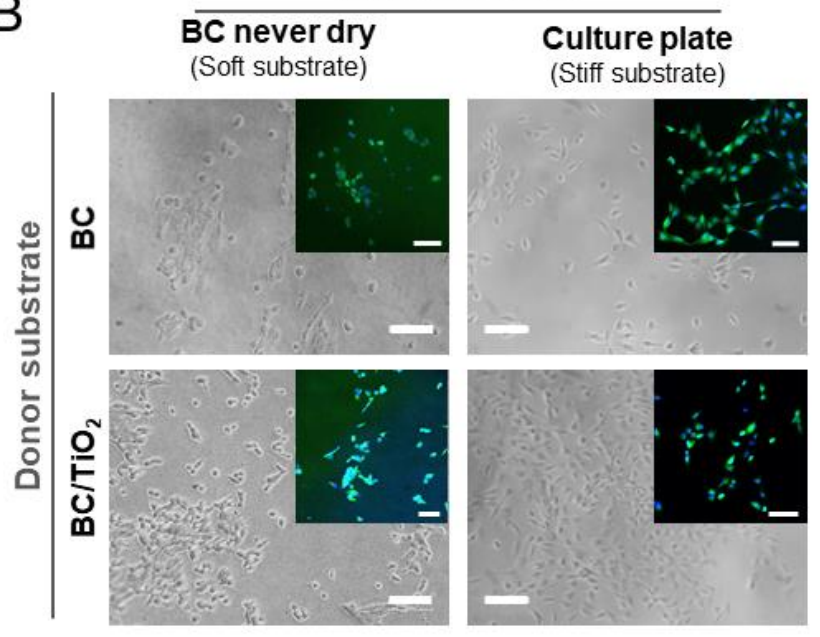

Figure 4: Cell retrievement from $\mathrm{BC}$ and $\mathrm{BC} / \mathrm{TiO}_{2}$ supports. A) Percentage of cells that could be harvested upon conventional enzymatic method with trypsin-EDTA. A higher percentage of cells $(55 \pm 18$ vs $35 \pm 15 \%$ ) was retrieved from the $\mathrm{BC} / \mathrm{TiO}_{2}$ substrates but this difference was not statistically significant $(\mathrm{P}$-value $=0.1965)$. The dashed line at $100 \%$ corresponds to the approximate percentage of cells recovered from polystyrene surfaces by the same procedure. B) Optical microscopy images of the migrated/transferred fibroblasts from the initial substrates $\left(\mathrm{BC}\right.$ and $\left.\mathrm{BC} / \mathrm{TiO}_{2}\right)$ to the new substrates: $\mathrm{BNC}$ hydrogels (soft substrate) and polystyrene cell culture surfaces (stiff substrate). Insets correspond to fluorescence microscopy images were cell nuclei are marked in blue (total number of cells) and viable cells are stained green with Calcein-AM. Scale bars $=100 \mu \mathrm{m}$.

\section{Adherent cell cryopreservation}

Cryobanking of adherent mammalian cells is challenging because of the need for low-temperature resistant substrates and the high risk of cell detachment after thawing ${ }^{47}$. We hypothesized that the mechanical and thermal stability of $\mathrm{BC}$ could be of great value for this application. Accordingly, we evaluated the possibility to directly cryopreserve cell-BC and cell-BC/TiO ${ }_{2}$ complexes aiming at facilitating the banking and transport of ready-to-use medical products based on $\mathrm{BC}^{48}$. BC-cells constructs were slowly frozen, stored on liquid nitrogen for over one week and thawed to assess cell viability and integrity of the $\mathrm{BC}$ and $\mathrm{BC} / \mathrm{TiO}_{2}$ supports.

Figure 5A shows the state of the fibroblast cultures grown on $\mathrm{BC}, \mathrm{BC} / \mathrm{TiO}_{2}$ and culture wells before cryopreservation and after thawing. Not surprisingly, 4 hours after defrosting, the cells were visibly stressed on the three tested conditions and decreased its viability down to 20-40\% compared to the not cryopreserved cultures. However, cells remained attached to the $\mathrm{BC}$ and $\mathrm{BC} / \mathrm{TiO}_{2}$ substrates and it was noticeable that, after a recovery time of 48 hours, the fibroblasts cultures became again highly confluent and viable as evidenced by the positive staining for Calcein-AM (see insets in Figure 5A) on the three experimental settings. Accordingly, the ATP levels measured $48 \mathrm{~h}$ after thawing (Figure 5B) of the cryopreserved cells were almost identical (no statistically significant differences) to the not cryopreserved samples. This corroborates the successful adherent cell cryopreservation on $\mathrm{BC}$ and $\mathrm{BC} / \mathrm{TiO}_{2}$ in a comparable fashion to the conventional cryopreservation method of single cells suspensions $(\mathrm{Ct})$. Notably, the suggested adherent cell cryopreservation process represents even an easier protocol compared to the control method since trypsinization is not required. The flexible nature of $\mathrm{BC}$ was helpful to place the substrates inside the cryovials and we speculate it is also convenient to prevent cell detachment as described in ${ }^{49}$ for a poly-urethane nanofibrous supports. Moreover, we assessed the integrity of $\mathrm{BC}$ and $\mathrm{BC} / \mathrm{TiO}_{2}$ substrates (without cells) after one-week storage at $-196{ }^{\circ} \mathrm{C}$. The films did not undergo any change in shape or consistency and were as easy to manipulate as the non- 
cryopreserved materials. Accordingly, the SEM micrographs of Figure 5C (BC) and 5D $\left(\mathrm{BC} / \mathrm{TiO}_{2}\right)$ show intact nanofibrillar structures and NPs coating without the presence of pores or cracks (use SEM images in Figure 1 for comparison). The finding that $\mathrm{BC}$ and $\mathrm{BC} / \mathrm{TiO}_{2}$ support the cryopreservation of adherent cells in an off-the-shelf format has important clinical significance as it could reduce the preparation time of cell loaded-biomaterials upon request and boarders the possibilities for long-term storage of cellular products ${ }^{48}$.

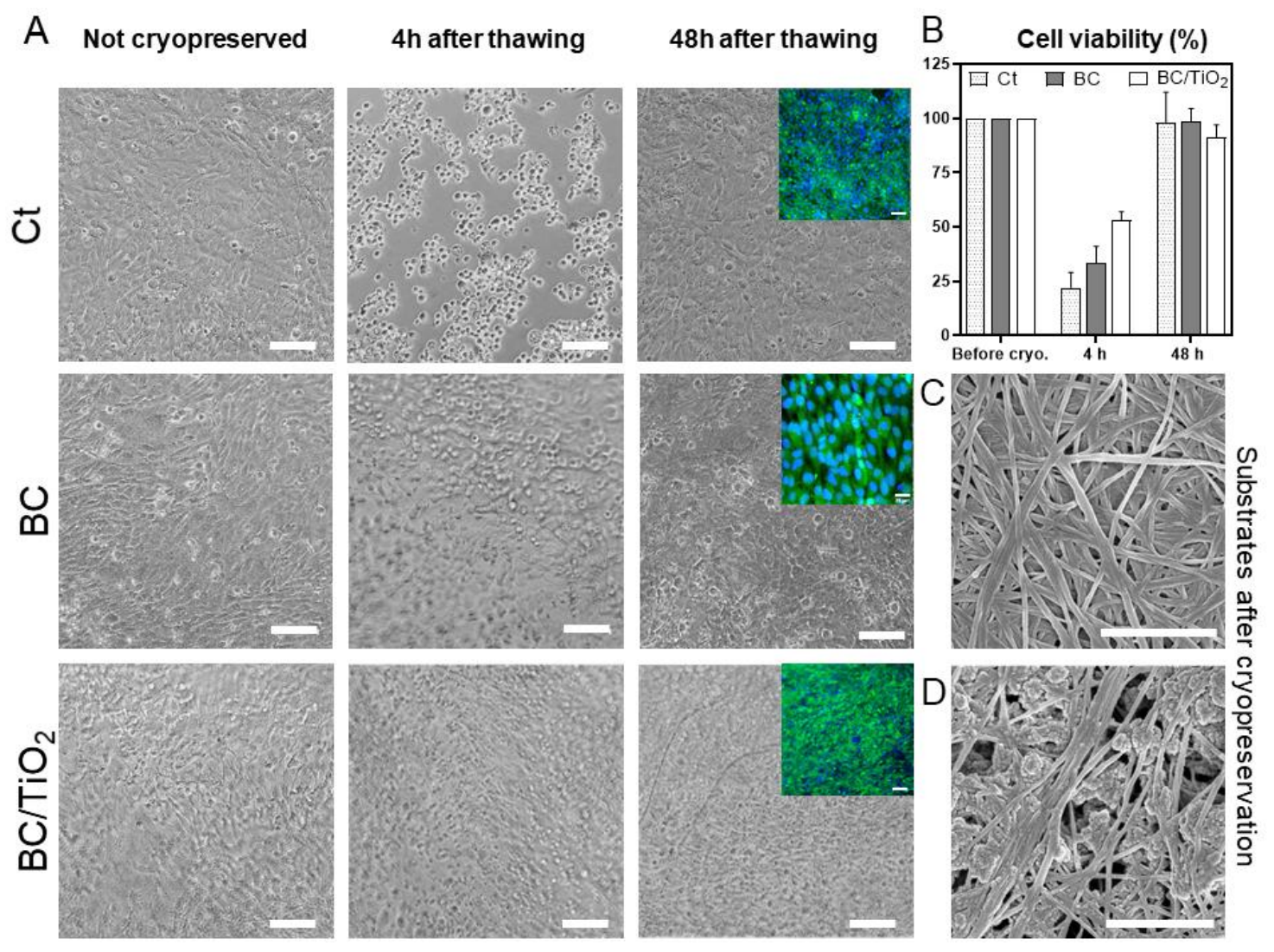

Figure 5: Adherent cell cryopreservation in $\mathrm{BC}$ and $\mathrm{BC} / \mathrm{TiO}_{2}$ substrates. A) Phase-contrast and fluorescent (insets showing Calcein-AM staining in green for viable cells) microscope images of fibroblasts grown on $\mathrm{BC}, \mathrm{BC} / \mathrm{TiO}_{2}$ and cell culture surfaces at the different evaluated points: before cryopreservation, $4 \mathrm{~h}$ and $48 \mathrm{~h}$ after thawing where cell recovery can be clearly appreciated. Scale bar $=100 \mu \mathrm{m}$. B) Cell viability after thawing expressed as a percentage of the not cryopreserved cultures. After 48 hours of incubation, the cryopreserved cells recover almost the same viability values as the not cryopreserved samples on the three assessed methods. C) $\mathrm{BC}$ and $\mathrm{D}$ ) $\mathrm{BC}_{\mathrm{TiO}}$ evaluation by scanning electron microscopy of the substrate's integrity after cryostorage. Note that the nanofibrillar structure is totally maintained after thawing on both substrates. Scale bar $=1 \mu \mathrm{m}$.

\section{CONCLUSIONS}

Here we endorse $\mathrm{BC}$ and $\mathrm{BC} / \mathrm{TiO}_{2}$ as endotoxin-free supports to expand human dermal fibroblasts by providing a complete evaluation of cellular responses towards $\mathrm{BC}$ and $\mathrm{BC} / \mathrm{TiO}_{2}$. No cytotoxic effects arising from the $\mathrm{TiO}_{2}$ nanoparticles anchored to the $\mathrm{BC}$ fibres have been detected while cell spreading on the hybrids was higher than in plain $\mathrm{BC}$. In this study, $\mathrm{TiO}_{2} \mathrm{NPs}$ were incorporated into the $\mathrm{BC}$ substrates to investigate its interactions with cells. However, future studies will examine other reported advantages of $\mathrm{TiO}_{2} \mathrm{NPs}$ such as the positive effect in wound healing and antimicrobial activity. Notably, we also report for the first time on the cryopreservation of cell-BC and cell- $\mathrm{BC} / \mathrm{TiO}_{2}$ constructs. Viable adherent cell cultures and undamaged carriers were thawed after $>$ one week in liquid nitrogen indicating that $\mathrm{BC}$ and its derivatives could be utilized in the fabrication and long-term storage of ready-to-use cellular 
products. We expect the findings reported here serve as a first step towards the development of BC-based cell transplantation supports paving the way for future uses of BC-nanocomposites as advanced biomaterials.

\section{ACKNOWLEDGEMENTS}

Authors acknowledge financial support from the Spanish Ministry of Science and Innovation through the RTI2018-096273-B-I00, project, the 'Severo Ochoa' Programme for Centres of Excellence in R\&D (SEV-2015-0496) and the PhD scholarships of I.A.S. (BE-2017-076734) and SRS (BES-2016-077533). The Generalitat de Catalunya with the 2017SGR765 and the 2019LLAV00046 projects are also acknowledged. The authors also express their gratitude to the technical services of ICMAB (Nanoquim, AFM and TGA), UAB (cell culture and microscopy facilities) and ICN2 (electron microscopy). The authors participate in the CSIC Interdisciplinary Platform for Sustainable Plastics towards a Circular Economy, SUSPLAST and in the Aerogels COST ACTION (CA 18125).

\section{SUPPORTING INFORMATION}

Detailed characterization of the $\mathrm{BC}$ and $\mathrm{BC} / \mathrm{TiO}_{2}$ substrates; phase contrast microscope images to illustrate cell proliferation; images before and after trypsinization; $\mathrm{BC}$ degradation by cellulase enzymes; large area confocal microscope images and details about the cell shape descriptors analysis are provided as supporting information.

\section{REFERENCES}

1. Boyce, S. T., Kagan, R. J., Meyer, N. A., Yakuboff, K. P. \& Warden, G. D. Cultured Skin Substitutes Combined With Integra Artificial Skin to Replace Native Skin Autograft and Allograft for the Closure of Excised Full-Thickness Burns. J. Burn Care Rehabil. 20, 453461 (1999).

2. O'Connor, N., Mulliken, J., Banks-Schlegel, S., Kehinde, O. \& Green, H. Grafting of burns with cultured epithelium prepared from autologous epidermal cells. Lancet 317, 7578 (1981).

3. Beele, H., de la Brassine, Lambert, J., Suys, E., De Cuyper, C., Decroix, J., Boyden, B., Tobback, L., Hulstaert, F., De Schepper, S., Brissinck, J., Delaey, B., Draye, J.-P., De Deene, A., DeWaele, P. \& Verbeken, G. A prospective multicenter study of the efficacy and tolerability of cryopreserved allogenic human keratinocytes to treat venous leg ulcers. Int. J. Low. Extrem. Wounds 4, 225-33 (2005).

4. Morino, T., Takagi, R., Yamamoto, K., Kojima, H. \& Yamato, M. Explant culture of oral mucosal epithelial cells for fabricating transplantable epithelial cell sheet. Regen. Ther. 10, 36-45 (2019).

5. Laurén, P., Somersalo, P., Pitkänen, I., Lou, Y., Arto Urtti, A., Partanen, J., Seppälä, J., Madetoja, M., Laaksonen, T., Mäkitie, A. \& Yliperttula, M. Nanofibrillar cellulosealginate hydrogel coated surgical sutures as cell-carrier systems. PLoS One 12, e0183487 (2017).6. Chua, A. W. C., Khoo, I. K., Truong, T. T. A., Woo, E., Tan, B. K. \& Chong, S. J. From skin allograft coverage to allograft-micrograft sandwich method: A retrospective review of severe burn patients who received conjunctive application of cultured epithelial autografts. Burns 44, 1302-1307 (2018).

7. Hervé, C., Pierre, A., Le Bever, H., Jean-Michel, R., Lakhel, A., Stephanazzi, J., Lambert, F. \& Perrot, J. Cultured epithelial autografts in extensive burn coverage of severely traumatized patients: a five year single-center experience with 30 patients. Burns 26, 379387 (2000).

8. MacNeil, S. Biomaterials for tissue engineering of skin. Mater. Today 11, 26-35 (2008). 
9. ter Horst, B., Chouhan, G., Moiemen, N. S. \& Grover, L. M. Advances in keratinocyte delivery in burn wound care. Adv. Drug Deliv. Rev. 123, 18-32 (2018).

10. Wood, F. M., Kolybaba, M. L. \& Allen, P. The use of cultured epithelial autograft in the treatment of major burn injuries: A critical review of the literature. Burns 32, 395-401 (2006).

11. Mitrousis, N., Fokina, A. \& Shoichet, M. S. Biomaterials for cell transplantation. Nat. Rev. Mater. 3, 441-456 (2018).

12. Brittberg, M. Cell carriers as the next generation of cell therapy for cartilage repair: A review of the matrix-induced autologous chondrocyte implantation procedure. Am. J. Sports Med. 38, 1259-1271 (2010).

13. de Oliveira Barud H., da Silva R., da Silva Barud H., Tercjak A., Gutierrez J., Lustri W., de Oliveira O. \& Ribeiro S. A multipurpose natural and renewable polymer in medical applications: Bacterial cellulose. Carbohydr. Polym. 153, 406-420 (2016).

14. Anton-Sales, I., D'Antin, C. J., Fernández-Engroba, J., Charoenrook, V., Laromaine, A., Roig A., \& Michael. R. Bacterial nanocellulose as a corneal bandage material: A comparison with amniotic membrane. Biomater. Sci. 8, 2921 (2020).15. Watanabe, K. et al. A new bacterial cellulose substrate for mammalian cell culture. Cytotechnology 13, 107-114 (1993).

16. Andrade, F. K., Moreira, S. M. G., Domingues, L. \& Gama, F. M. P. Improving the affinity of fibroblasts for bacterial cellulose using carbohydrate-binding modules fused to RGD. J. Biomed. Mater. Res. Part A 92, 9-17 (2010).

17. Gonçalves, S., Padrão, J., Rodrigues, I. P., Silva, J. P., Sencadas, V., Lanceros-Mendez, S., Girão, H., Dourado, F. \& Rodrigues, L. R. Bacterial Cellulose As a Support for the Growth of Retinal Pigment Epithelium. Biomacromolecules 16, 1341-1351 (2015).

18. Gonçalves, S., Rodrigues, I. P., Padrão, J., Silva, J.P., Sencadas, V., Lanceros-Mendezc, S., Girão, H., Gama, F. M., Dourado, F. \& Lígia R. Rodrigues- Acetylated bacterial cellulose coated with urinary bladder matrix as a substrate for retinal pigment epithelium. Colloids Surfaces B Biointerfaces 139, 1-9 (2016).

19. Lv, X., Yang, J., Feng, C., Li, Z., Chen, S., Xie, M., Huang, J., Li, H., Wang, H. \& Xu, Y. Bacterial Cellulose-Based Biomimetic Nanofibrous Scaffold with Muscle Cells for Hollow Organ Tissue Engineering. ACS Biomater. Sci. Eng. 2, 19-29 (2016).

20. Svensson, A., Nicklasson, E. Harrah, T., Panilaitis, B., Kaplan, D.L., Brittberg, M. \& Gatenholm, P. Bacterial cellulose as a potential scaffold for tissue engineering of cartilage. Biomaterials 26, 419-431 (2005).

21. Khan, S., Ul-Islam, M., Ikram, M., Islam, S. U., Ullah, M. W., Israr, M., Jang, J. H., Yoon, S. \& Park, J. K. Preparation and structural characterization of surface modified microporous bacterial cellulose scaffolds: A potential material for skin regeneration applications in vitro and in vivo. Int. J. Biol. Macromol. 117, 1200-1210 (2018).22. Tronser, T., Laromaine, A., Roig, A. \& Levkin, P. A. Bacterial Cellulose Promotes LongTerm Stemness of mESC. ACS Appl. Mater. Interfaces 10, 16260-16269 (2018).

23. Anton-Sales, I., Beekmann, U., Laromaine, A., Roig, A. \& Kralisch, D. Opportunities of Bacterial Cellulose to Treat Epithelial Tissues. Curr. Drug Targets 20, 808-822 (2019).

24. Fey, C., Betz, J., Rosenbaum, C., Kralisch, D., Vielreicher, M., Friedrich, O., Metzger, M. \& Zdzieblo, D. Bacterial nanocellulose as novel carrier for intestinal epithelial cells in drug delivery studies. Mater. Sci. Eng. C 109, 110613 (2020).

25. Jagannath, A., Raju, P. S. \& Bawa, A. S. Comparative evaluation of bacterial cellulose 
(nata) as a cryoprotectant and carrier support during the freeze drying process of probiotic lactic acid bacteria. LWT - Food Sci. Technol. 43, 1197-1203 (2010).

26. Lee, K. H., Sun, J. C., Chuang, C. K., Guo, S. F., Tu, C. F. \& Ju, J. C. An efficient and mass reproducible method for vitrifying mouse embryos on a paper in cryotubes. Cryobiology 66, 311-317 (2013).

27. Benjamin Stielow, J., Vaas, L. A. I., Göker, M., Hoffmann, P. \& Klenk, H. P. Charcoal filter paper improves the viability of cryopreserved filamentous ectomycorrhizal and saprotrophic Basidiomycota and Ascomycota. Mycologia 104, 324-330 (2012).

28. Ullah, H., Wahid, F., Santos, H. A. \& Khan, T. Advances in biomedical and pharmaceutical applications of functional bacterial cellulose-based nanocomposites. Carbohydr. Polym. 150, 330-352 (2016).

29. Osumi, K., Matsuda, S., Fujimura, N., Matsubara, K., Kitago, M., Itano, O., Ogino, C., Shimizu, N., Obara, H. \& Kitagawa, Y. Acceleration of wound healing by ultrasound activation of TiO2 in Escherichia coli-infected wounds in mice. J Biomed Mater Res Part $B$ 105, 2344-2351 (2017).

30. Seisenbaeva, G. A., Fromell, K., Vinogradov, V. V., Terekhov, A, N., Pakhomov, A. V., Nilsson, B., Ekdahl, K. N., Vladimir V. V. \& Kessler, V. G. Dispersion of TiO2 nanoparticles improves burn wound healing and tissue regeneration through specific interaction with blood serum proteins. Sci. Rep. 7, 15448 (2017).

31. Galkina, O. L., Ivanov, V. K., Agafonov, A. V., Seisenbaeva, G. A. \& Kessler, V. G. Cellulose nanofiber-titania nanocomposites as potential drug delivery systems for dermal applications. J. Mater. Chem. B 3, 1688-1698 (2015).

32. Galkina, O. L., Önneby, K., Huang, P., Ivanov, V. K., Agafonov, A. V., Seisenbaeva, G. A. \& Kessler, V. G. Antibacterial and photochemical properties of cellulose nanofibertitania nanocomposites loaded with two different types of antibiotic medicines. J. Mater. Chem. B 3, 7125-7134 (2015).

33. Khalid, A., Ullah, H., Ul-Islam, M., Khan, R., Khan, S., Ahmad, F., Khan, T. \& Wahid, F. Bacterial cellulose- $\mathrm{TiO} 2$ nanocomposites promote healing and tissue regeneration in burn mice model. $R S C A d v$. 7, 47662-47668 (2017).

34. Roig-Sanchez, S., Jungstedt, E., Anton-Sales, I., Malaspina, D. C., Faraudo, J., Berglund, L. A., Laromaine, A. \& Roig, A. Nanocellulose films with multiple functional nanoparticles in confined spatial distribution. Nanoscale Horizons 4, 634-641 (2019).

35. May-Masnou, A., Soler, L., Torras, M., Salles, P., Llorca, J. \& Roig, A. Fast and Simple Microwave Synthesis of TiO2/Au Nanoparticles for Gas-Phase Photocatalytic Hydrogen Generation. Front. Chem. 6, 110 (2018).

36. U.S. Department of Health and Human Services et al. Guidance for Industry Pyrogen and Endotoxins Testing: Questions and Answers. http://www.fda.gov/Drugs/GuidanceComplianceRegulatoryInformation/Guidances/defau lt.htmhttp://www.fda.gov/BiologicsBloodVaccines/GuidanceComplianceRegulatoryInfo rmation/Guidances/default.htm (2012).

37. Zeng, M., Laromaine, A. \& Roig, A. Bacterial cellulose films: influence of bacterial strain and drying route on film properties. Cellulose 21, 4455-4469 (2014).Zeng, M., Laromaine, A. \& Roig, A. Bacterial cellulose films: influence of bacterial strain and drying route on film properties. Cellulose 21, 4455-4469 (2014).

38. Biazar, E., Heidari, M., Asefnejad, A., Asefnezhad, A. \& Montazeri, N. The relationship between cellular adhesion and surface roughness in polystyrene modified by microwave plasma radiation. Int. J. Nanomedicine 6, 631-9 (2011). 
39. Zareidoost, A., Yousefpour, M., Ghaseme, B. \& Amanzadeh, A. The relationship of surface roughness and cell response of chemical surface modification of titanium. J Mater Sci Mater Med 23, 1479-88 (2012).

40. Martínez Ávila, H., Feldmann, E. M., Pleumeekers, M. M., Nimeskern, L., Kuo, W., de Jong, W. C., Schwarz, S., Müller, R., Hendriks, J., Rotter, N., van Osch, G. J. V. M., Stok, K. S. \& Gatenholm, P. Novel bilayer bacterial nanocellulose scaffold supports neocartilage formation in vitro and in vivo. Biomaterials 44, 122-133 (2015).

41. Hakkinen, K. M., Harunaga, J. S., Doyle, A. D. \& Yamada, K. M. Direct Comparisons of the Morphology, Migration, Cell Adhesions, and Actin Cytoskeleton of Fibroblasts in Four Different Three-Dimensional Extracellular Matrices. TISSUE Eng. Part A 17, (2011).

42. Huber, M. D. \& Gerace, L. The size-wise nucleus: nuclear volume control in eukaryotes. J. Cell Biol. 179, 583-4 (2007).

43. Milla, M., Yu, S.-M. \& Laromaine, A. Parametrizing the exposure of superparamagnetic iron oxide nanoparticles in cell cultures at different in vitro environments. Chem. Eng. J. 340, 173-180 (2018).

44. Yeung, T., Georges, P. C., Flanagan, L. A., Marg, B., Ortiz, M., Funaki, M., Zahir, N., Ming, W., Weaver, V., \& Janmey, Paul A. Effects of substrate stiffness on cell morphology, cytoskeletal structure, and adhesion. Cell Motil. Cytoskeleton 60, 24-34 (2005).

45. Matsuura, K., Utoh, R., Nagase, K. \& Okano, T. Cell sheet approach for tissue engineering and regenerative medicine. J. Control. Release 190, 228-239 (2014).

46. Yamato, M. \& Okano, T. Cell sheet engineering. Mater. Today 7, $42-47$ (2004).

47. Ng, K., Gao, B., Yong, K. W., Li, Y., Shi, M., Zhao, X., Li, Z., Zhang, X. H., PingguanMurphy, B., Yang, H. \& Xu, F. Paper-based cell culture platform and its emerging biomedical applications. Materials Today vol. 20 32-44 (2017).48. Costa, P. F., Dias, A. F., Reis, R. L. \& Gomes, M. E. Cryopreservation of Cell/Scaffold TissueEngineered Constructs. TISSUE Eng. Part C 18, (2012).

49. Batnyam, O., Suye, S. \& Fujita, S. Direct cryopreservation of adherent cells on an elastic nanofiber sheet featuring a low glass-transition temperature. RSC Adv. 7, 51264-51271 (2017). 


\section{TABLE OF CONTENTS}

Bacterial nanocellulose and titania hybrids: cytocompatible and cryopreservable cell carriers

Irene Anton-Sales, Soledad Roig-Sanchez, María Jesús Sánchez-Guisado, Anna Laromaine* and Anna Roig*

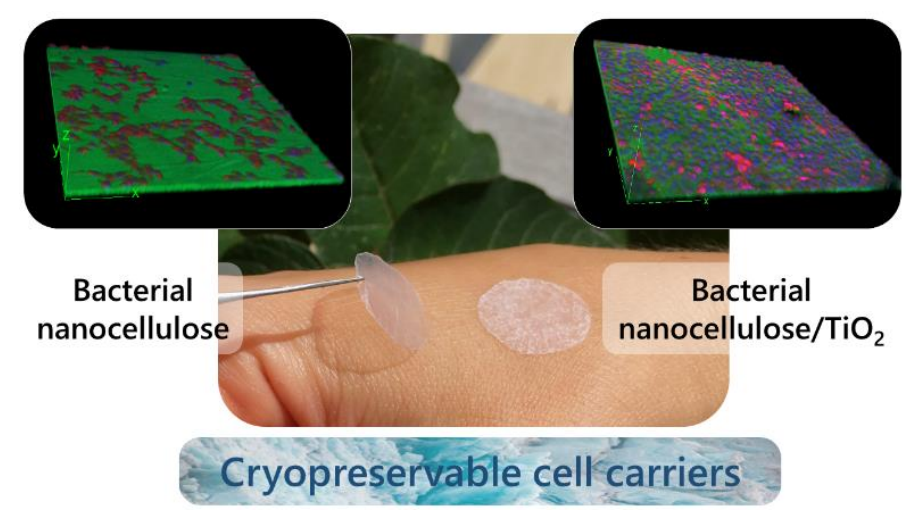

